than the history text," declared US Commissioner of Education Ernest L. Boyer. "Our job as communicators as well as educators is to recognize the world has changed ... and to find ways to relate the classroom more closely to the networks of information beyond the classroom." 40

Many of these media experiments faltered in the 1980s, as the Reagan administration curtailed federal education spending, encouraged back-to-basics curricula, and deprioritized low-income students' needs. These policy shifts hobbled the child-centered pedagogy and affective agendas underlying many Coleman-inspired television experiments. Nonetheless, the Coleman Report's findings had fundamentally changed policymakers' attitudes toward television's educational possibilities. They had helped draw pedagogy and consumer culture closer in the 1960s and 1970s, legitimizing television's use in curricula and promoting the medium as a productive tool for the development of affective and cognitive skills in and out of the classroom. And the conviction that entertainment-oriented and commercial media can effectively complement formal education has persisted well into the digital age.

doi: $10.1017 /$ heq.2017.34

\title{
If Opportunity Is Not Enough: Coleman and His Critics in the Era of Equality of Results
}

\author{
Leab N. Gordon
}

Six years after James Coleman's Equality of Educational Opportunity (1966) asked whether educators could effectively equalize opportunity for low-income African American and Latino students in the nation's increasingly segregated cities, sociologist Christopher Jencks

\footnotetext{
${ }^{40}$ Ernest L. Boyer, "Opening Remarks," in Cole, Television, the Book, and the Classroom, 11-12.

Leah Gordon is Lewis-Sebring Visiting Associate Professor of History and American Studies at Amherst College. She authored From Power to Prejudice: The Rise of Racial Individualism in Midcentury America (Chicago: University of Chicago Press, 2015) and is currently working on Imagining Opportunity: Education and Equality in Modern America (forthcoming). She thanks Matthew Kelly and Laura Marcus for research assistance and the American Council of Learned Societies for research support. She also thanks her fellow panelists and HEQ editors for their feedback.
} 
questioned whether Coleman had been asking too much from American schools. If the goal was equality of opportunity broadly conceived, Jencks held, then schools were the wrong tools; efforts to equalize educational opportunity were simply a distraction from the real goal of equalizing opportunity in life. ${ }^{1}$ A year later, Black Panther leader Huey P. Newton also questioned whether equal educational opportunity was a myth. In his 1973 autobiography, he argued that his Oakland schools had been structured to block the American dream:

This was how we grew up-in a close family with a proud, strong, protective father and a loving, joyful mother. ... We shared the dreams of other American children. In our innocence we planned to be doctors, lawyers, pilots, boxers, and builders. How could we know then that we were not going anywhere? Nothing in our experience had shown us yet that the American dream was not for us. We, too, had great expectations. And then we went to school. ${ }^{2}$

When finding that at graduation he and his friends "were ill-equipped to function in society, except at the bottom," Newton speculated that school leaders "knew what they were doing, preparing us for the trash heap of society, where we would have to work long hours for low wages."3 Coleman, Jencks, and Newton were all disappointed by the public schools' failure to equalize educational or socioeconomic opportunities. In expressing this disappointment, they echoed another famous critique of opportunity-based egalitarianism of the civil rights, Black Power, and Great Society eras: President Lyndon Johnson's 1965 call for "equality as a fact and equality as a result." ${ }^{4}$ However, these social thinkers approached the debates over the meanings and purposes of educational equality that rocked the educational establishment in the late 1960s and 1970s with very different explanations of the sources of inequality — and different visions of a just society - in mind.

These contests over educational equality in the decade following the Civil Rights Act represent one flashpoint in a longer history of disagreements concerning the meanings of educational equality, on the

\footnotetext{
${ }^{1}$ James S. Coleman et al., Equality of Educational Opportunity (1966; repr. New York: Arno Press, 1979); and Christopher Jencks et al., Inequality: A Reassessment of the Effect of Family and Schooling in America (New York: Basic Books, 1972). 2009), 16.

${ }^{2}$ Huey P. Newton, Revolutionary Suicide (1973; repr. New York: Penguin Books, ${ }^{3}$ Ibid., 50.

${ }^{4}$ Lyndon B. Johnson, "Remarks at the Howard University Commencement" (June 4, 1965), http://archive.millercenter.org/president/lbjohnson/speeches/ speech-3387.
} 
one hand, and whether schools could equalize society on the other. Imprecisely defined but widely celebrated, equality of opportunity (one strand of American egalitarian thought) has been among the most enduring and broadly embraced political ideals in twentiethcentury America. ${ }^{5}$ Efforts to equalize adult socioeconomic status have always been controversial, but few oppose-at least openly and in principle - giving all children a fair chance to get ahead. At the same time, since at least the 1940s, critics on the left have argued that opportunity-based egalitarianism was a myth or ideology that rationalized an unequal status quo and led Americans to ask too much of their schools. $^{6}$ One piece of that larger story, this paper explores Americans' contested visions of the role schools can and should play in generating a fair social order, as well as the questions those discussions raised about how much equality, and what types, are necessary in a just society.

An examination of these issues, especially in years alternately described as the Coleman Report, War on Poverty, Moynihan Report, and Black Power eras, engages three historiographies. First, it provides a history of a social and political ideal that builds on what cultural historians and scholars of "the politics of knowledge" have shown about how social categories evolve over time and are

${ }^{5}$ On the history of opportunity liberalism, especially in the Great Society era, see Gareth Davies, From Opportunity to Entitlement: The Transformation and Decline of Great Society Liberalism (Lawrence: University Press of Kansas, 1996). For philosophical and historical work on the competing interpretations of equality of educational opportunity, see Debra Satz, "Equality, Adequacy, and Education for Citizenship," Ethics 117, no. 4 (July 2007), 623-48; Christopher Jencks, "Whom Must We Treat Equally for Educational Opportunity to Be Equal?," Ethics 98, no. 3 (April 1988), 518-33; Adam Nelson, The Elusive Ideal: Equal Educational Opportunity and the Federal Role in Boston's Public Schools, 1950-1985 (Chicago: University of Chicago Press, 2005); and Adam R. Nelson, "Rodriguez, Keys, Lau, and Milliken Revisited: The Supreme Court and the Meaning of 'Equal Educational Opportunity,' 1973-1974," in To Educate a Nation: Federal and National Strategies of School Reform, ed. Carl Kaestle and Allyssa E. Lodewick (Topeka: University Press of Kansas, 2007), 202-24. On equality and equal opportunity more broadly, see Peter Westen, "The Concept of Equal Opportunity," Ethics 95, no. 4 (July 1985), 837-50; and J. R. Pole, The Pursuit of Equality in American History (Berkeley: University of California Press, 1978).

${ }^{6}$ W. Lloyd Warner, Robert J. Havighurst, and Martin B. Loeb, Who Shall Be Educated? The Challenge of Unequal Opportunities (New York: Harper, 1944), 146; Jencks et al., Inequality; Michael B. Katz, Class, Bureaucracy, and Schools: The Illusion of Educational Change in America (New York: Praeger, 1975) 109, xxii; David Labaree, "The Winning Ways of a Losing Strategy: Educationalizing Social Problems in the United States," Educational Theory 58 no. 4 (Nov. 2008), 447-60; and Harvey Kantor and Robert Lowe, "From New Deal to No Deal: No Child Left Behind and the Devolution of Responsibility for Equal Opportunity," Harvard Educational Review 76, no. 4 (Dec. 2006), 474-502. 
shaped by institutional pressures. ${ }^{7}$ The concept of equal opportunity evolved as it moved between social science, social policy, literature, and popular social thought-discursive locations that, in part, determined the ideal's evolving contours. Second, by centering American thought about the relationship between schooling, employment, housing, and social welfare policy, this larger project integrates histories of education and American liberalism. Why Americans never committed to a more redistributive social welfare state has long occupied historians of twentieth-century liberalism. ${ }^{8}$ The Coleman moment suggests that the hope that schooling could equalize society was part of the story of liberalism's blind spots, even, as Harvey Kantor and Robert Lowe suggest, in cases where social science raised more questions than it answered about how education for equality actually worked. ${ }^{9}$ And third, in conversation with African American intellectual and political history, this paper situates visions of schooling's egalitarian potential in the wider history of American thought on race and class injustice, debates that became especially discordant as the interracial left fractured in the 1960s and 1970s. ${ }^{10}$

${ }^{7}$ Matthew Frye Jacobson, Whiteness of a Different Color: ,European Immigrants and the Alchemy of Race (Cambridge, MA: Harvard University Press, 1998); Sarah E. Igo, The Averaged America: Surveys, Citizens, and the Making of a Mass Public (Cambridge, MA: Harvard University Press, 2007); Ellen Condliffe Lagemann, The Politics of Knowledge: The Carnegie Corporation, Philanthropy, and Public Policy (Middletown, CT: Wesleyan University Press, 1989); and Alice O'Connor, Poverty Knowledge: Social Science, Social Policy, and the Poor in Twentieth-Century U.S. History (Princeton, NJ: Princeton University Press, 2001).

${ }^{8}$ On American liberalism, see Gary Gerstle, "The Protean Character of American Liberalism," American Historical Review 99, no. 4 (Oct. 1994), 1043-73; John David Skrentny, The Ironies of Affirmative Action: Politics, Culture, and Justice in America (Chicago: University of Chicago Press, 1996), 23; Davies, From Opportunity to Entitlement, and Alan Brinkley, The End of Reform: New Deal Liberalism in Recession and War (New York: Vintage Books, 1995). On education and social welfare policy, see Miriam Cohen, "Reconsidering Schools and the American Welfare State," History of Education Quarterly 45 no. 4 (2005), 512-37; Tracy Lynn Steffes, School, Society, and State: A New Education to Govern Modern America, 1890-1940 (Chicago: University of Chicago Press, 2012); David Labaree, Someone Has to Fail: The Zero-Sum Game of Public Schooling (Cambridge, MA: Harvard University Press, 2010); and Katz, Class, Bureaucracy, and Schools. On this theme in the War on Poverty era, see Kantor and Lowe, "From New Deal to No Deal"; Michael B. Katz, The Undeserving Poor: America's Enduring Confrontation With Poverty, 2nd ed. (New York: Oxford University Press, 2013, Chapter 3; and Thomas J. Sugrue, Sweet Land of Liberty: The Forgotten Struggle for Civil Rights in the North (New York: Random House, 2008), 365-66.

${ }^{9}$ Harvey Kantor and Robert Lowe, "What Difference Did the Coleman Report Make?," History of Education Quarterly 57, no. 4 (Nov. 2017), XX.

${ }^{10}$ I take the term interracial left from Sugrue, Sweet Land of Liberty. Though he uses it to discuss the 1930s, it is also a useful concept for describing social thought about race and class in the 1960s and 1970s. On varieties of antiracism, liberalism, and 
Historians often discuss the Coleman Report as a time when views of educational equality shifted focus from educational inputs (funding, teacher quality, facilities, curricula) to educational outputs (test scores); when research on what would later be termed the achievement gap was launched; and when arguments over whether integration or compensatory education represented the best tool for equalizing educational opportunities reached a crescendo. ${ }^{11}$ When considering the politics of egalitarian thought on education in the civil rights and Black Power eras, however, the views of Coleman's critics were as important as his-though in the long term not as influential. ${ }^{12}$ One set of critiques, which emerged from a group of (largely white) social scientists with loose ties to the socialist-leaning New Left, suggested that what Coleman missed was schooling's limited capacity to equalize social and economic status among adults, at least in the absence of redistributive tax, employment, or welfare policies. The other line of critique, which emerged from the internally

radicalism in the civil rights, Black Power, and War on Poverty eras, see Clayborne Carson, In Struggle: SNCC and the Black Awakening of the 1960s (Cambridge, MA: Harvard University Press, 1981); Thomas F. Jackson, From Civil Rights to Human Rights: Martin Luther King, Jr., and the Struggle for Economic Justice (Philadelphia: University of Pennsylvania Press, 2007); Peniel E. Joseph, Waiting 'Til the Midnight Hour: A Narrative History (New York: Holt, 2006); Katz, The Undeserving Poor, 50101; Wendell E. Pritchett, Brownsville, Brooklyn: Blacks, Jews, and the Changing Face of the Ghetto (Chicago: University of Chicago Press, 2002); Russell John Rickford, We Are an African People: Independent Education, Black Power, and the Radical Imagination (New York: Oxford University Press, 2016); Sugrue, Sweet Land of Liberty, 356-448; Robert Self, American Babylon: Race and the Struggle for Postwar Oakland (Princeton, NJ: Princeton University Press, 2003); William L. Van Deburg, New Day in Babylon: The Black Power Movement and American Culture, 1965-1975 (Chicago: University of Chicago Press, 1992); and Joy Ann Williamson, Black Power on Campus: The University of Illinois, 1965-1975 (Urbana: University of Illinois Press, 2003).

${ }^{11}$ Coleman et al., Equality of Educational Opportunity; Joseph F. Kett, Merit: The History of a Founding Ideal from the American Revolution to the 21st Century (Ithaca, NY: Cornell University Press, 2013), 240-41; Nelson, The Elusive Ideal; and James T. Patterson, Freedom Is Not Enough: The Moynihan Report and America's Struggle over Black Family Life from LBJ to Obama (New York: Basic Books, 2010). The Harvard Educational Review and the Journal of Negro Education published special issues in response to the Coleman Report in 1968. A number of compilation volumes emerged as well, including Harvard Educational Review, eds., Equal Educational Opportunity (Cambridge: Harvard University Press, 1969); and Frederick Mosteller and Daniel P. Moynihan, eds., On Equality of Educational Opportunity: Papers Deriving from the Harvard University Faculty Seminar on the Coleman Report (New York: Random House, 1972).

${ }^{12}$ The long-term legacy of the Coleman Report is evident in contemporary achievement gap research as well as in the attention that the report received from leading research and funding institutions on its fiftieth anniversary. For examples of conferences, retrospectives, and compilation volumes, see Kantor and Lowe, "What Difference Did the Coleman Report Make?" 
diverse African American left, argued that Coleman blamed the victim because he failed to account for systemic and institutionalized racial discrimination both within and outside of schools. Where Coleman's critics disagreed was on the relative importance of liberal capitalism and institutionalized racism as obstacles to educational equality, on the role schooling (even antiracist schooling) could play in struggles to equalize the economic order, and on the most politically strategic way to discuss the sources of the achievement gap. Certainly, the Coleman Report's federal sponsorship, combined with the rigor, scale, and innovative character of Coleman's quantitative analysis, partly account for the report's long-term impact on the educational research and policy establishment. What this paper reveals is that differences in egalitarian vision and political strategy among Coleman's critics-including the fear that questioning schooling's egalitarian capacities could be politically disastrous for low-income and minority youth-also help explain why Coleman's useful, but incomplete, explanation of educational inequality had such staying power.

An emblem of Great Society liberalism's enthusiasm for both quantitative social science and educational responses to poverty, Coleman's enormous, government-sponsored statistical analysis of the relationship between educational inputs and outputs revealed much that commentators already knew. The sociologist found that the nation's schools were segregated by race and socioeconomic status, that segregation was generally coupled with inequality in educational resources, and that while minority children lagged behind whites in their "verbal and nonverbal skills when they enter the first grade," schools seemed to make matters worse. ${ }^{13}$ And yet the most controversial aspect of the Coleman Report was the finding-one he hadn't expected and that shocked an education policy establishment hopeful about compensatory education-that minority children's academic performance was not substantially affected by increasing educational inputs. Although most minority students attended schools where they had less access to resources (facilities like science labs and libraries, curricula, and extracurricular offerings like school newspapers or debate teams) that seemed related to academic success, these "variations in the facilities and curriculums of the schools," Coleman concluded, "account for relatively little variation in pupil achievement insofar as this is measured by standard tests." ${ }^{14}$ Coleman's finding

${ }^{13}$ Coleman et al., Equality of Educational Opportunity, 8-9, 3, 21. For useful summaries of the report, also see James Coleman, "The Concept of Equality of Educational Opportunity," Harvard Educational Review 38, no. 1 (1968), 7-22 and Kett, Merit, 240-41.

${ }^{14}$ Coleman et al., Equality of Educational Opportunity, 22; For a discussion of how this conclusion sent "seismic shocks through the academic and bureaucratic worlds of 
about what later scholars termed peer effects, the idea that the test scores of poor and minority students seemed to increase when they were in classes with middle-class peers, produced more hope, at least for integrationists who saw the report as a mandate for largescale desegregation plans, including through busing. ${ }^{15}$ Advocates of community-controlled schooling and compensatory education, however, worried that the report rationalized reduced investments in African American educational spaces. ${ }^{16}$

Partly in response to Equality of Educational Opportunity, and alongside studies of social mobility and the life course by Peter Blau and Otis Duncan, leftist white social scientists at some of the nation's most prestigious universities launched one line of critique: they asked whether equality of educational opportunity could generate opportunity in life. ${ }^{17}$ Making liberal capitalism without sufficient safety nets the primary obstacle to American egalitarian aspirations, sociologist Jencks and economist Samuel Bowles suggested that asking education to equalize life chances in the absence of other egalitarian social and economic programming was futile. ${ }^{18}$ Bowles criticized the Coleman Report for underestimating the extent to which educational inputs (especially teacher quality) affected academic progress among

education" see Godfrey Hodgson, "Do Schools Make a Difference?" in the 'Inequality' Controversy: Schooling and Distributive Justice, ed. Donald M. Levine and Mary Jo Bane (New York, Basic Books, 1975), 22-44, 27.

${ }^{15}$ Coleman et al., Equality of Educational Opportunity, 21-22; For discussions, some critical, of Coleman's analysis of the impact of the class and racial composition of a student body on minority student academic achievement see: Alan B. Wilson, "Social Class and Equal Educational Opportunity," in Equal Educational Opportunity, ed. Harvard Educational Review (Cambridge, MA: Harvard University Press 1969), 84-87; US Commission on Civil Rights, Racial Isolation in the Public Schools (Washington, DC: Government Printing Office, 1967); and Charles H. Thompson, "Race and Equality of Educational Opportunity: Defining the Problem," Journal of Negro Education 37, no. 3 (July 1968), 191-203, 197-98.

${ }^{16}$ On resistance to the negative portrayal of black educational spaces, see Noel Day, "The Case for All-Black Schools," in Equal Educational Opportunity, ed. Harvard Educational Review (Cambridge, MA: Harvard University Press, 1969), 205-12; Charles Hamilton, "Race and Education: A Search for Legitimacy," in Harvard Educational Review, Equal Educational Opportunity, 187-202; and Kenneth Clark, "Alternative Public School Systems," in Harvard Educational Review, Equal Educational Opportunity, 173-86. On Pan-African and liberation schools in the 1960s and 1970s, see Rickford, We Are an African People. On struggles over community control, see Pritchett, Brownsville, Brooklyn; and Jack Dougherty, More Than One Struggle: The Evolution of Black School Reform in Milwaukee (Chapel Hill: University of North Carolina Press, 2004).

${ }^{17}$ Peter Michael Blau and Otis Dudley Duncan, The American Occupational Structure (New York: Wiley, 1967).

${ }^{18}$ Samuel Bowles, "Toward Equality of Educational Opportunity?," Harvard Educational Review 38, no. 1 (April 1968), 89-99; and Jencks et al., Inequality. 
racial minorities and for downplaying "the effectiveness of devoting more resources to the education of Negro children."19 Ultimately, however, Bowles was as concerned with the impact of labor market discrimination as low test scores on African American employment prospects. In a 1968 response to Coleman, he argued that "the earnings gap considerably exceeds the learning gap" and that understanding "the effects of education on jobs and the effects of education on income" was as important as understanding achievement gaps. ${ }^{20}$ "Equality of educational opportunity implies major changes in society at large," he maintained, including changes in the "distribution of political power between races and among social classes" and "cannot be achieved by the efforts of the educational system alone." 21 The volume most closely aligned with this critique was Jencks and colleagues' Inequality (1972), which concluded that increasing educational opportunity would have little effect on social status among adults, especially on inequalities in employment, income, or job satisfaction. "The character of a school's output depends largely on a single input, namely the characteristics of the entering children," Jencks offered in a statement that, unsurprisingly, put many educators on edge. "Everything elsethe school budget, its policies, the characteristics of the teachers-is either secondary or completely irrelevant." ${ }^{22} \mathrm{He}$ argued further, prefiguring an argument historian Michael Katz would make two years later, that educational reform could displace or obscure broader social reform. ${ }^{23}$ "As long as egalitarians assume that public policy cannot contribute to economic equality directly but must proceed by ingenious manipulations of marginal institutions like the schools," Jencks argued, "progress will remain glacial." In fact, exposing the radical associations that led many in the education establishment to discount his analysis, Jencks noted, "If we want to move beyond this tradition, we will have to establish political control over the economic institutions that shape our society. This is what other countries usually call socialism." 24

In the decade following the passage of the Civil Rights Act, another set of thinkers also questioned the Coleman Report, but with a different set of concerns in mind. This group, from across the internally divided African American left, turned attention to an issue

\footnotetext{
${ }^{19}$ Bowles, "Toward Equality of Educational Opportunity?," 90.

${ }^{20}$ Ibid., 98, 95-96.

${ }^{21}$ Ibid., 90 .

${ }^{22}$ Jencks et al., Inequality, 255-56.

${ }^{23}$ For an example of this argument in Michael Katz's work two years later, see Katz, Class, Bureaucracy, and Schools, 109.

${ }^{24}$ Jencks et al., Inequality, 265.
} 
Coleman largely overlooked: institutionalized racial discrimination within and outside of schools. ${ }^{25}$ Black Power leaders Stokely Carmichael and Charles V. Hamilton consistently treated opportunity-based egalitarianism as an ideology rationalizing white supremacy. ${ }^{26}$ In contrast, African American integrationists closer to the liberal center, including Charles H. Thompson, recently retired editor of the Journal of Negro Education and dean of Howard University's School of Education; Whitney Young, executive director of the Urban League; and psychologist Kenneth B. Clark called emphatically for equality of educational opportunity, often as a way to promote compensatory notions of racial justice. These thinkers, in contrast to Coleman, did not shy away from causal arguments. But they treated systemic and institutionalized racism-not the family and community context that Coleman pinpointed or the inequalities capitalism inherently generated, which Bowles and Jencks highlighted — as the chief obstacle to the equalization of educational opportunities. They also situated educational inequality squarely within the wider political and economic context of deindustrializing, increasingly segregated metropolitan America. ${ }^{27}$

Clark's Dark Ghetto avoided Coleman's causal ambiguity and associated victim-blaming by clearly presenting school-based discrimination as a primary source of poor academic achievement among lowincome African American youth in Harlem. The book was based largely on qualitative survey and ethnographic material compiled through Harlem Youth Opportunities Unlimited, an educational, employment, and social service organization the psychologist established in 1962. In fact, Clark highlighted the systematic character of school-based discrimination in part because he rejected narrow versions of scholarly objectivity in favor of an approach that, "would not permit 'the facts to interfere with the truth." 28 In Clark's view, pernicious racist assumptions-including the notion that pushing black children academically would hurt their self-esteem and that advanced schooling would only prove disillusioning since black youth would be

${ }^{25}$ For an example of Coleman's efforts to assess students' sense of control over life chances, an issue he thought might expose discrimination, though it could also be used to stigmatize (by suggesting that low motivation accounted for achievement gaps), see Coleman et al., Equality of Educational Opportunity, 289.

${ }^{26}$ Kwame Ture and Charles V. Hamilton, Black Power: The Politics of Liberation (1967; repr. New York: Vintage, 1992), Kindle edition, chap. 1, paragraph 38.

${ }^{27}$ Kenneth B. Clark, Dark Ghetto: Dilemmas of Social Power (New York: Harper and Row, 1965) 111-15; and Whitney M. Young, To Be Equal (New York: McGraw Hill, 1964) 51-100; 139-162. See also Thompson, "Race and Equality of Educational Opportunity," 191.

${ }^{28}$ Clark, Dark Ghetto, xxiii, xix. 
forced into menial work-were institutionalized in educational policy and practice in Harlem's white-run schools, providing educators with "an alibi for educational neglect." 29 In much the same way that "if an arm or a leg is bound so that it cannot be used, eventually it becomes unusable," in a statement that both pathologized students and blamed schools for academic failure, Clark argued, "children who are treated as if they are uneducable almost invariably become uneducable." ${ }^{30}$ Clark was hardly alone in highlighting the consequences of systemic, institutionalized educational discrimination. Concern with this issue had long motivated African American resistance to biased testing, tracking, disciplinary, curricular, and guidance programs. ${ }^{31}$ Experiences with overt and subtle forms of educational racism were also a ubiquitous theme in autobiographies-like Huey Newton'spublished by African Americans in the 1960s and 1970s. ${ }^{32}$

Writers on the African American social scientific left also challenged Coleman's causal premises by robustly contextualizing. While Coleman acknowledged white flight, he tended to isolate educational inequality from inequality in other sectors of social, economic, and political life. ${ }^{33}$ Many thinkers on the African American left, in contrast, suggested that one could not understand educational inequality without situating schools in a wider context of racial inequality in the nation's increasingly segregated and deindustrializing urban cores. Young, an expert on urban social welfare policy and fair housing, put the real estate practices and federal, state, and local housing

${ }^{29}$ Ibid., 126-27.

${ }^{30}$ Ibid., 128.

${ }^{31}$ Davidson M. Douglas, Jim Crow Moves North: The Battle over Northern School Segregation, 1865-1954 (New York: Cambridge University Press, 2005), 163-66, 178-79; Kathryn M. Neckerman, Schools Betrayed: Roots of Failure in Inner-City Education (Chicago: University of Chicago Press, 2007); John L. Rury and Shirley A. Hill, The African American Struggle for Secondary Schooling, 1940-1980: Closing the Graduation Gap (New York: Teachers College Press, 2012) 104-108; Sugrue, Sweet Land of Liberty, 163-199 and 449-492; Young, To Be Equal, 123; Pritchett, Brownsville, Brooklyn; and Rickford, We Are an African People, 32-33.

${ }^{32}$ Lorraine Hansberry, To Be Young, Gifted, and Black: Lorraine Hansberry in Her Own Words, adapted by Robert Nemiroff (1969; repr. New York: Vintage, 1995), 35; Lenny Wilkens, The Lenny Wilkens Story (New York: Paul S. Erickson, 1974) 23-24; Malcolm $\mathrm{X}$ and Alex Haley, The Autobiography of Malcolm X (1964; repr. New York: Penguin Books, 2001), 118-20; Dick Gregory, Nigger: An Autobiography (New York: Dutton, 1964), 46; Robert Lee Grant, with Carl Gardner, The Star Spangled Hustle (Philadelphia: Lippincott, 1972), 31-32; Everett Frederick Morrow, Way Down South Up North (Philadelphia: United Church Press, 1973), 17; and James Forman, The Making of Black Revolutionaries: A Personal Account (New York: MacMillan, 1972), $31,46-47$.

${ }^{33}$ On Coleman's acknowledgement of white flight, see Coleman, Equality of Educational Opportunity, 32. 
policies that built segregated residential contexts where educational inequality flourished at the center of his analysis. ${ }^{34}$ Clark situated his discussion of Harlem's schools in an expansive theory of internal colonialism. ${ }^{35}$ In a response to the Coleman Report, Thompson emphasized that "the task of obtaining equality of educational opportunity" could not be separated from efforts "to obtain equal opportunity for employment, equal access to decent housing ... equal opportunity to enjoy public accommodations ... equal opportunity to participate in the body politic" and all other basic civil rights. ${ }^{36}$

In fact, Young was particularly well positioned to examine educational inequality with an eye to the wider political, economic, and sociological context. His vantage point from outside the world of educational research and policy (a perspective that Coleman's broad sociological training, theoretically, also provided) left Young concerned about the dangers of institutional siloing. As the Urban League leader put it when explaining the challenges of fighting urban African American poverty: "The real estate man or the builder says the problem is economic; business, or the employer, says the problem is education; and the educators say that the problem is a matter of housing." ${ }^{37}$ This vision of shifting blame translated into multipronged proposals for fighting urban, racialized poverty. Young proposed a comprehensive federal initiative-what he termed an "unprecedented domestic 'Marshall Plan" - that included housing, employment, health care, educational, and criminal justice programs to fight African American urban poverty. In doing so, he echoed the "Freedom Budget for All Americans" that A. Philip Randolph, Bayard Rustin, and others tried unsuccessfully to push through Congress in $1966 .{ }^{38}$ Critiques of the egalitarian potential of schooling

\footnotetext{
${ }^{34}$ For an example of the language of "a war on many fronts" from the 1940 s, see Martin D. Jenkins, "Editorial Comment: Education for Racial Understanding," Journal of Negro Education, 13, no. 3 (July 1944), 266-67. For examples from the long tradition of social scientific work on "the race problem," see W. E. B. Du Bois, The Philadelphia Negro (1899; repr. New York: Cosimo Classics, 2007); Charles S. Johnson, The Negro in American Civilization: A Study of Negro Life and Race Relations in the Light of Social Research (New York: Henry Holt, 1930); Gunnar Myrdal, An American Dilemma: The Negro Problem and Modern Democracy (New York: Harper, 1944); and E. Franklin Frazier, The Negro Family in the United States (New York: McMillan, 1957).

${ }^{35}$ Clark, Dark Ghetto, 11. On theories of internal colonialism, see Katz, The Undeserving Poor, 50-101; and Nikhil Pal Singh, Black Is a Country: Race and the Unfinished Struggle for Democracy (Cambridge, MA: Harvard University Press, 2005), 174-211.

${ }^{36}$ Thompson, "Race and Equality of Educational Opportunity," 191.

${ }^{37}$ Young, To Be Equal, 18.

${ }^{38}$ Ibid., 26; and Sugrue, Sweet Land of Liberty, 375-77.
} 
(if functioning in isolation) in a racist society were not limited to social policy arenas either. These ideas also emerged from African American autobiographies of the 1960s and 1970s, which featured a recurring storyline in which an author recalled the precise moment when he or she learned (usually from a disillusioned older friend or relative) that labor market discrimination would hamper employment prospects, regardless of educational credentials. ${ }^{39}$ If learning could liberate, many across the African American left acknowledged soberly, it could not do so alone.

While they discussed the issue in different language, then, what Coleman's diverse critics recognized was that even if equal educational opportunity could be defined and promoted, schooling might not be able to equalize access to stable, middle-class jobs and the standard of living that accompanied them. In contrast to Jencks and Bowles, however, many on the African American left simultaneously embraced the "learning for liberation" tradition by envisioning schooling as a central (though never the only) tool for African American political and psychological empowerment. ${ }^{40}$ In fact, highlighting the ways attention to systemic racial discrimination emerged hand in hand with commitment to liberation-oriented schooling, Newton was one of many Black Power leaders to establish separatist, Pan-African, or liberation schools premised on the notion that the right type of education could be individually and collectively empowering. ${ }^{41}$

So how did the debates over education's relationship to racial equality that divided an increasingly fractious interracial left in the 1960s and 1970s relate to the Coleman Report's long-term impact. The precise combination of political, methodological, and theoretical pressures that explain why the Coleman Report had wider influence in educational research and policy than the report's critics demands further investigation. Certainly, as I've argued elsewhere, and as others in this issue make clear, that the federal government chose Coleman to use cutting-edge statistical techniques on one of the largest datasets

${ }^{39}$ Shirley Chisholm, Unbought and Unbossed (Boston: Houghton Mifflin, 1970) 23; and Tom Skinner, Black and Free (New York: New Family Library, 1974) 40-41.

${ }^{40}$ For a few of the many works on learning for liberation, see James Anderson, The Education of Blacks in the South (Chapel Hill: University of North Carolina Press, 1988); Hilary Moss, Schooling Citizens: The Struggle for African American Education in Antebellum America (Chicago: University of Chicago Press, 2009); Rickford, We Are An African People; and Vanessa Siddle Walker, Their Highest Potential: An African American School Community in the Segregated South (Chapel Hill: University of North Carolina Press, 1996).

${ }^{41}$ Rickford, We Are an African People. 
thus far available enhanced his scholarly authority. ${ }^{42}$ This is especially the case when one views his work alongside Clark's qualitative, impressionistic approach or Young's application-oriented social policy research.

What is also clear, however, is that the racial blind spots of some of Coleman's white leftists critics were also part of the story. The Coleman Report, and the controversies it generated, emerged amid not only Moynihan Report-style deficiency paradigms (and Daniel Moynihan, it should be recalled, strongly supported Coleman's research) but also as Arthur Jensen revived hereditarian explanations of racial inequality. ${ }^{43}$ Both paradigms angered civil rights and Black Power communities because they made it easy to blame the victims of racial injustice for their plight. In this context, many publishing in the African American social scientific and popular press worried that the view that schools were insufficient egalitarian tools, which they associated with both the Coleman Report and Jencks's Inequality, was itself "antiegalitarian." ${ }^{44}$ In fact, that Jencks's volume combined skepticism about schooling's economic potential with an argument about "inequality in cognitive skills" led some to draw a straight line between Jencks and Jenkins. ${ }^{45}$ In Ebony, an anonymous author responded to Inequality with outrage, writing:

The message to the poor man is plain. If white people deny you food and shelter, if they conspire to destroy the minds and bodies of your children, if they arrange social processes so that two black babies die for every white baby, then it is all your fault, you poor slob. Or, to be more precise, it is your mamma's fault. ${ }^{46}$

The African American social scientific press, while more cautious in tone, also addressed the issue. Jencks's research, Journal of Negro

\footnotetext{
${ }^{42}$ Leah Gordon, "Causality, Context, and Colorblindness: Equal Educational Opportunity and the Politics of Racist Disavowal," in Seeing Race Again: Countering Colorblindness Across the Disciplines, ed. Kimberle Crenshaw, et al. (Berkeley: University of California Press, forthcoming). On the importance of Coleman's methodological innovation to his long-term impact, see Kantor and Lowe, "What Difference Did the Coleman Report Make?" and Ethan L. Hutt, "Seeing Like a State' in the Postwar Era: The Coleman Report, Longitudinal Datasets, and the Measurement of Human Capital," History of Education Quarterly 57, no. 4 (Nov. 2017), XX.

${ }^{43}$ On Moynihan's support for Coleman, see Patterson, Freedom Is Not Enough, 103.

${ }^{44}$ Day, "The Case for All-Black Schools"; and Hamilton, "Race and Education: A Search for Legitimacy."

${ }^{45}$ For a critique of arguments about the hereditability of intelligence in Jencks's Inequality, see Letter to the Editor, "The Scholarly Dozens," Ebony, Nov. 1, 1972, 192-93.

${ }^{46}$ Ibid.
} 
Education author Charles Martin feared, would be "incorporated into public policy by an antiegalitarian government" that would reject his socialist leanings and simply use the analysis to ensure that "the amount of money for schooling and the amount of schooling for black people will be significantly reduced." ${ }^{77}$ Even those who saw Jencks's treatment of cognitive skills as more nuanced than the author of the piece in Ebony (who was attacked by another editorialist for not reading Inequality carefully enough), criticized Jencks for "letting schools off the hook." 48 In fact, one of Inequality's lead researchers, Marshall Smith, was forced to resign from a position as acting commissioner of education in the Carter administration in 1979 after the Congressional Black Caucus protested due to his work on Inequality, a book they described as having "racist overtones." 49

Certainly, points of overlap exist in the two counternarratives about schooling's egalitarian potential this paper has examined. Both sets of thinkers challenged the Coleman Report's emphasis on the cultural and academic failures of minority parents, teachers, and communities; questioned Coleman's tendency to separate educational inequality from the political, economic, and spatial contexts in which it was situated; and rejected Coleman's focus on educational opportunity (and outcomes) without considering opportunity in life. Still, differences in emphasis remain striking. Concern with systemic or institutionalized racism both inside and outside schools emerged most robustly from African American intellectual circles, while educational discrimination took on a secondary role in Jencks's and Bowles's critiques of schooling. Scholars across a diverse African American left also remained distinctly hopeful about schooling's egalitarian promise in a liberal society, if only institutionalized racism in schools and beyond were effectively challenged. Perhaps most importantly, as controversies over desegregation, community control, and compensatory education raged in the mid-1960s, and then as Nixon-era "law and order" politics and attacks on "forced busing" accelerated by the early 1970s, African American leftists frequently rejected arguments -including the suggestion that schools might be insufficient egalitarian tools - that could rationalize reduced commitments to desegregation or educational funding for minority students. Even Coleman's

${ }^{47}$ Charles A. Martin, "There's More Than One Way to Skin a Cat," Journal of Negro Education 42, no. 4 (Oct. 1973), 559-69, 566.

${ }^{48}$ Robert G. Newby, "Desegregation-Its Inequities and Paradoxes," Black Scholar 11, no. 1 (Sept. 1979), 17-28, 67-68; Carl Senna, letter to the editor, Ebony, Feb. 1, 1973, 19.

${ }^{49}$ Spencer Rich, "Education Office Nominee Blocked by Black Caucus," Washington Post, June 27, 1979, A1; and "Ed. Commissioner Quits Under Caucus Pressure," Jet, July 26, 1979, 25. 
critics, then, feared that acknowledging the real complexity of the relationship between education and equality might undermine the larger goal of improving educational quality for students in need.

doi: $10.1017 /$ heq.2017.35

\title{
"Seeing Like a State" in the Postwar Era: The Coleman Report, Longitudinal Datasets, and the Measurement of Human Capital
}

\author{
Ethan L. Hutt
}

Nearly a half-century later, Christopher Jencks's 1969 quip that "like a veritable Bible, the 'Coleman Report,' is cited today on almost every side of every major educational controversy" continues to ring true. ${ }^{1}$ Whether the issue is the efficiency of schools, the imperative of integration, or the capacity of public education to solve social problems, the debate-public and scholarly-occurs in the shadow of the Coleman Report.

Though it is difficult to deny the Coleman Report's singular influence on conversations about American schooling, historians of education have an important role in properly situating it not just in the research on inequality or school effectiveness but also within larger historical narratives. There are two such narratives, in particular, that I hope to highlight here. The first concerns the historical development and operation of the "American education state"-that is, the variety of people, institutions, and governance structures that have both composed and constructed the American public education

Ethan Hutt (ehutt@umd.edu) is an Assistant Professor at the University of MarylandCollege Park. This essay is part of ongoing work on the history of data collection and research on American schools. He would like to thank the audiences at the annual meetings of the History of Education Society and the Organization of American Historians as well as Nancy Beadie and Joy Williamson-Lott for their thoughtful feedback.

${ }^{1}$ James S. Coleman et al., Equality of Educational Opportunity (1966; repr., New York: Arno Press, 1979); and Christopher Jencks, "A Reappraisal of the Most Controversial Educational Document of Our Time: The 'Coleman Report," New York Times Magazine, Aug. 10, 1969, 12. 